\title{
4. From Gift to Commodity ... . and Back Again: Form and Fluidity of Sexual Networking in Papua New Guinea
}

\section{LAWRENCE HAMMAR}

Because, when you are a woman, you don't just sit still and do nothingyou have lovers ... One man gives you only one kind of food to eat. But when you have lovers, one brings you something and another brings you something else. One comes at night with meat, another with money, another with beads. Your husband also does things and gives them to you (Nisa, to Shostak 1981, 271).

Hey little girl, ooh, sweet little Honey.

I'm gonna give you, all of my money.

All I'm asking is, give it to me when I come home

(Otis Redding, the original 'Respect').

The mature and sexually experienced [chimpanzee] female trades upon her ability to satisfy the sexual urges of the male (Yerkes 1943, 86).

With all my worldly goods I thee endow [the Bride, who then replies to the Groom:] With my body I thee love (traditional marriage vow).

\section{Introduction}

In this essay I want to contribute to longstanding discussions about sexism and marriage, gender relations and sexuality, and prostitution and public health in Papua New Guinea (PNG). My contribution is aimed at two overlapping developments and discourses. First, since at least the late 1970s, calls have been made for the PNG state to erect and regulate brothels, ostensibly as a 'public health' measure to prevent the transmission of STDs, but also to sequester the signs of sexuality away from public view. Sex is bad, but prostitution is lust, 
being both unproductive and wasteful. Prostitution-related topics appeared throughout the 1970s in newspapers such as The Independent, the Post-Courier, and the Wantok (in Tok Pisin). They set the stage for the first several years' worth of AIDS-related coverage and the current struggles over the question of brothels. Four of the first six articles published in the Post-Courier, after the first HIVab+ case had been reported (in 1987), implicated prostitution (July 2, $3,6,10,22$, and 24). As would be the case throughout the following 20 years, letter-writers, editors, and public health officials blamed prostituted women for the growing HIV crisis without presenting any evidence of transmission dynamics. Nor did they show concern for the women, their sexual partners and families, or the conditions under which they might have been infected, including through rape.

Significant protest against the erection of brothels continues to come from the church and other authorities, although few voices and even fewer authorities protest from feminist principles or concern about possible human rights violations. Nevertheless, proposals are increasingly being made by highranking politicians, businessmen and health officials (sometimes one and the same) to erect brothels as a response to the emerging AIDS crisis. It is true that state-sponsored brothels can be argued to 'work' well in preventing STD and HIV transmission elsewhere, for example, in Thailand, Melbourne, or certain counties in the American state of Nevada. Nevertheless, state-sponsored brothels in PNG would require 'regulation' by members of the 'disciplined' forces (who aren't) and whose 'force' is often greatest when their 'discipline' is weakest. ${ }^{1}$ For this reason alone - one of the many paradoxes engendered in weak states - they will not 'work' in PNG.

There are other reasons, too, however, which this essay explores. In addition to the shortfall of truly disciplined powers and the corresponding excess of male dominance in such matters, proposals to erect and maintain brothels dramatically understate the medical and regulatory powers that would be required of the PNG state to ensure an increase in levels of condom usage in the brothels sufficient to dent fast-rising rates of HIV transmission and, in many places, near-epidemic levels of untreated STDs. My colleagues at the Institute of Medical Research (IMR), for instance, routinely demonstrate STD prevalence rates that approach or exceed 30 percent, in 40 percent or more of communities sampled (e.g. Tiwara et al. 1996; Gare et al. 2005; Hammar 2006). As well, state-sponsored brothels would surely increase already significant female sexual exploitation. As sexual minorities, women and girls already take rhetorical and literal poundings daily in 'prostitution' and in plain-old 'marriage', both terms which here gloss truly

\footnotetext{
1 See works by Luker and Dinnen, Stewart, Shearing, Fletcher, and Jenkins here in this volume, and those of these fine scholars plus also Bradley, Clark, Gillett, Hammar, Hughes, Knauft, Macintyre, Reid, Wardlow, Zimmer-Tamakoshi and others, elsewhere.
} 
stupefying diversity in form and meaning of styles, locations and outcomes of sexual networking. Most Christian and customary doctrines and practices regarding land, money, reproduction and sex, assume that males have God- or ancestor-given rights to control the sexual and reproductive health of females with more or less unhindered male sexual access. This is neither healthy nor morally just. As I have argued at length elsewhere (e.g. Hammar 2004a, b; 1998), and as others have argued in other ways, it constitutes the widespread and deeply entrenched sexually transmitted dis-ease (the hyphen is intentional) on the level of social structure that is nevertheless felt also at the level of the individual. Few church, political, health or donor voices wish unblinkingly to examine such premises in thinking afresh about the origins of the 'current' AIDS crisis, which are in fact longstanding.

Second, in this essay I touch upon the historical and other forces that have shaped, and been shaped by, changes in sexual networking forms. I present data that I and others collected previously, and that I and my colleagues collected from 2003-2006 while undertaking a nationwide study of HIV/AIDS, STDs and sexual health and human behaviour for the Papua New Guinea Institute of Medical Research (PNGIMR) (Hammar 2006). Most examples are drawn from four locales: Lae (2004); Daru (1990-2, 2003-4); Port Moresby (1991, 2003-5); and Moro, Southern Highlands Province (2005, 2006). Throughout the essay I suggest that the differences between 'prostitution' and 'marriage', not being self-evident, require sociological analysis. The absence of social scientific perspectives in informing policy and public health debates in PNG cannot stand, ${ }^{2}$ for the very future of PNG - weak state or not - hangs in the balance.

\section{From Gift to Commodity . . . and Back Again}

Each of the four quotations that appear at the outset imagine ideal gender relations, among European peasants, chimpanzees, African-Americans and the !Kung San hunter-gatherers of the Kalahari desert. Despite differences in space, time and political economy, each example suggests that the differential access that females have to the means of production - be they arrows, jobs, termite mounds, or land - is (but is only partly) mitigated by, through and because of sex, whether given, traded, bought or sold. Insofar as hunter-gatherers represent the primordial human subsistence strategy, and given that the !Kung San are held to be gender-egalitarian, Nisa's fuller story affirms the universal nature of

2 I do not mean that social science research hasn't been done or done sufficiently well as to inform such debates, but rather, that the response to HIV and AIDS in PNG since 1987 has been to stack national- and local-level bodies with physicians and public health workers, politicians and church leaders at the expense of sociologists, activists, and anthropologists. 
sexism and male prerogative. In exchange for sex, her foraging skills and a little piece of her heart, Nisa expects meat, money and beads from different kinds of sex partners, including her husband.

To some researchers, that Nisa receives goods for sex constrains her value as a woman and marks her second-class status as a person, even amongst this seemingly egalitarian people. If she were allowed to string a bow, fire an arrow, or earn wages, that is, she wouldn't need a husband. To others, Nisa's sexual agency expresses the complementary nature of labor divisions (between hunting and gathering, in this case) and indexes the high value of women. Nisa's suitors get sex, mongongo nuts and trading partners (what they need), while she receives beads, food and money (what she needs).

Similar disputes abound regarding the degree to which male breadwinnerheaded households cause, correlate with, or help mitigate male domination in commerce, religion and culture. The traditional marriage vow cited above ('With all my worldly goods ...') seems to verbalise the structural imbalance of compulsory heterosexuality and the fact that women's options are fewer and more bodily than men's. Crossing the human/non-human primate divide, some early claims made about chimpanzee sociality by the famous primatologist, Robert Yerkes, so projected male fantasy-how would he know anything about female chimpanzee sexual skills? - that an extremely mature female chimpanzee, 'Josie', savaged him in the glorious satire, Adam's Rib (Hershberger 1948). Papua New Guinean readers might appreciate knowing that lengthy genealogies exist in primatology and kindred fields that tried in racist fashion to argue for similarities between the real and imagined sexual behaviours of chimpanzees, gorillas and baboons and those of the human beings living nearby-indeed, to many, more darkly complected peoples. In 'Respect', Otis Redding's R\&B classic, the protagonist expects 'it' (sex) in exchange for his paycheck. The song was covered and punctuated rather differently ('R-E-S-P-E-C-T'), however, by Aretha Franklin, whose second-wave feminist anthem tellingly contains a mumbled acronym: 'T.C.B.' ('Takin' Care of Business'). The infectious refrains of 'Whip it ta me' and 'Sock-it ta me, sock-it ta me ...' seem further to nudge open the envelope of male economic power, female desire and the ease with which the gifts of love turn into the commodities of sex. ${ }^{3}$ Chris Gregory, in his ground-breaking treatise on Melanesian sociality, Gifts and Commodities (1982, 116), notes that 'a thing is now a gift, now a commodity, depending on the social context of the transaction'.

3 Indeed, fascinating debates too lengthy and complicated to pursue here have turned on this question of 'gift' and/or/versus 'commodity' in Melanesian sociality (see works by especially Marilyn Strathern, Aletta Biersack, Chris Gregory and others). 
PNG is a particularly good country with which to put some of these ideas to the test. Both older (e.g. Sinclair 1981) and more recent (e.g. Gammage 1998) narratives demonstrate that, on contact with Westerners and other kinds of Melanesians, Papua New Guinean men and male corporate groups were already trading female sexual access and that women were themselves sexually networking in diverse, complicated ways. The 'Professional Beauties' of Normanby Island, the Bukan cargo cult-related 'Baby Gardens', the Sepik river area 'war captives' and the shell-earning canoe tours that some new brides made in the Papuan Gulf (see Hammar 1998, n.d.) are just some of the many types that can be found in the ethnological, colonial administrative and mission literature.

In only a few decades post-Contact, sexual networking outside marriages made formally in churches (which are themselves statistically rare) has come to include:

- formal or quasi-brothels, patronised by 'disciplined' forces and male landowners;

- kastom marit, in which parents quickly consume bride-price paid by often much older workmen or landowners;

- informal brothels and male social clubs, such as are operated in villages adjacent to sites of resource extraction or in the settlements of Port Moresby;

- gentlemen's clubs in Port Moresby's lounge-bars and members' rooms where young Papuan females earn commissions by convincing men to buy highpriced drinks;

- temporary marriages around sites of resource extraction involving expatriate workers, some of whom leave children behind;

- streetwalking or freelance prostitution near motel front-gates, betel-nut selling stands, male workers' quarters, black-market liquor shops and along roads;

- motels and guest-houses, where sex is facilitated by security guards, bar managers and taxi-cab drivers, who draw from well-known females nearby;

- 'wet lunches' in which mid-level public servants solicit high-school girls and younger female colleagues for in-office sex;

- tu kina bus, or cheap, quick, largely anonymous sex in outdoor bush locales;

- rot meri (in the rural areas) and road runners (in Port Moresby) who stand arms and legs akimbo adjacent to roads and streets, sometimes advertised by male handlers;

- pasindia meri, who were first sold by families as the Highlands Highways was nearing completion, but who later entered sexual networking in protest against ill treatment by male relatives; and

- $\quad$ let kaikai, in which women sell sex in exchange for takeaway food. 
Sexual networking in PNG is driven by the gendered antagonisms of social structure and political economy, but also by significant female agency. Rules of kinship and land ownership, marriage and religious expression, sexuality and political representation, and schooling options and post-marital residence patterns, express existing tensions between structure and agency and bring new tensions to the surface. It is men, not women, who get security guard positions, receive royalty payments and become political leaders, but usually women, not men, who sell sexual services and bear the brunt of spousal drinking and violence.

The following examples are familiar enough. A Balimo girl is enticed into sex with her 8th-grade teacher, which allows her to pay school fees and receive better marks. However, she becomes pregnant and is forced to leave school and her village, and ends up selling sex in Port Moresby. A 45 year-old Daru widow has sex with a hotel employee to gain long-distance telephone access with which to beg a potential suitor to return home. A 17 year-old girl in Moro is plucked from tu kina bus and married by an oil pipeline worker but who will likely leave her when he learns of her previous marriage (at age 11), current infections and seeming infertility. Goroka secretaries suffer sexual harassment so as to keep a job, and would-be clerks have to sell themselves to Malaysian shop-owners just to get one. Bingo- and 7 Card-addled 'housewives' near Tububil slink off to the bush for furtive sex with young fellows so as to get back into the game. At roadside stands (known in Tok Pisin as kakaruk maket) along the Highlands Highway, women sell sex (or extend 'credit') to keep Self and Family afloat. Girls and women in Lae are forced into sex with warders in lieu of bail money. Tari women know as early as do landowners the timing and amounts of royalties to be paid out and so seek help from policemen getting there, even if they have to 'give' sex to them to do so. Police cars in Vanimo are known as pamuk teksi (taxis for promiscuous females), which suggests something of the kind and extent of involvement in prostitution by this arm of the disciplined forces. If asked, any Port Moresby taxi driver can tell you from which Papuan settlement he procures females for businessmen, tourists and political leaders.

Sexual networking therefore tracks along lines of inequality and accepted sociality. 'Nobody answers a job ad to become a pamuk', but lacking available 'sexual scripts' that would instruct them in sexual physiology and performance, many Papua New Guinean girls must cement sexual knowledge and improve sexual skills 'through direct experience' (Delta 2005). Some network sexually to obtain alcohol and transportation or to bring food into the house. Others engage in it to escape dreary settlements, mitigate low wages, or avoid greedy male relatives and love-sick, toea-short boyfriends. Rules and norms of sociality in PNG mean that the non-material 'gifts' of sexual expression preceding sanctioned relationships can easily turn into 'commodities' (expected rice- 
packets, rides and telephone bill payments), but then back again into the 'gifts' of ongoing material support and social status ('housewife', 'married') that is imagined to offset the gendered imbalances of political economy.

Like political economy, marriage and compulsory heterosexuality exhibit many structural contradictions. Men can marry concurrently while women cannot. Widowerhood is not onerous compared to widowhood. Men commit sexual violence with virtual impunity, especially in marriage. Physically and otherwise immature females are routinely married against their will to much older husbands. For many married women shelter, food and an acceptable social status come dearly: some husbands whip out the Bible and read from the Book of Ephesians to justify their 'right' to 'use' their wives, and others say 'Em putim pe pinis, ya'! ('He already paid brideprice'!).

Both marriage and prostitution exhibit stupefying diversity of form and evince complicated social processes. Not surprisingly, one begets the other begets the other on a continuum of connectedness. When Christian missionaries in PNG forbade polygyny and dissolved the 'married' status of all but the first wife, they sometimes consigned the remainder to prostitution because of double standards about divorce and sexually 'used' bodies (Willis 1974). Having refused marriage altogether, having preferred women sexually, or having refused to re-marry following abusive relationships, many English women became political prisoners aboard the Botany Bay-bound 'floating brothels' of 1788 and thereafter (Rees 2002). The boyfriends and husbands they often found aboard, however, just as do husbands in many PNG cultures, for example, the Kiwai, Hanuabada, Kikori and Bamu, also pimped them both aboard and upon disembarkation. A clinic in Tokyo that treats long-married women found that 26 percent of their clients had not had sex in the previous year with their husbands, who have 'pornography and the sex industry to take care of their needs' (Kim, in McCurry 2005). The clinic finds paying boyfriends for the wives. Some highlight the degree of affectivity involved to distinguish marriage from prostitution. However, just as not every customer is nice, neither are all husbands, if statistics regarding marital rape and wife-battering in PNG are even half-right (e.g. Zimmer-Tamakoshi 2004).

In short, it is not so simple to parse between, on the one hand, culturally acceptable (because they are not nakedly commercial) forms of sexual networking that ideally occur between two affective spouses who will have sex with each other again, and on the other hand, the more obviously commercialised forms of sexual networking but which can nevertheless feature greater duration, love and respect, and less anonymity than some 'successful' marriages. Many women come to marriage following stints in prostitution. Many women come to prostitution following miserable marriages and/or sexually abusive childhoodssex they neither asked for nor were paid for. Men are persons qua men, but because women have second-class (or worse) access qua women to the means of 
production, they must sell their kina (in Tok Pisin, the national currency, a shell traditionally used to pay bride-price, but also vagina). Without allowing access to their golmain (gold-mine) or opening their maket (both meaning vagina), many women in PNG would simply die. Neither are renewable resources, as timber might someday be in PNG. In terms of prevailing public health messages and campaigns, and given settings of ubiquitous sexual networking and sexual violence, should women even be asked, much less be expected to 'stay faithful' to a single partner so as to avoid AIDS? Readers may judge for themselves whether such messages, common in PNG, were ever really about preventing transmission. I believe that they were not, but even assuming that they were, they haven't worked. They haven't worked for fairly predictable sociological reasons, for fundamentally misunderstanding of the nature and function of sex industries in PNG and the tenor of marital relationships.

\section{Sex Industries in Papua New Guinea}

Cross-cultural and historical studies of sex industries elsewhere show clearly that new and/or transformed types of sexual networking, such as those in PNG mentioned above, tend to simultaneously maintain existing and forge new gender, ethnic and other relations. Dreams of a post-colonial PNG are dashed at any number of clubs, hotels and other venues throughout Port Moresby and elsewhere. Faltering colonial and masculine ideologies are massaged thereoften quite literally - as middle-aged (and older) working-class expatriates are paired with young Papuan females. Male drinkers, on the other hand, are separated into opposing classes of private 'members' (expatriates) and 'public' drinkers (nationals), though there are exceptions.

Sex industries thrive also on male privilege in sex, kinship and marriage, and in 'tradition' - and religion-induced shame about sex, communication and bodies. Inter-tribal relations and historical forces also matter. It was Gumine women (and not Gogodala) who first migrated to Port Moresby en masse with male relatives in the early to -mid-1970s and set up and operated quasi-brothels because Simbu already predominated in security firms, motel management, long-distance trucking and taxi-cab driving-locales and services crucially important to prostitution. Highlands women generally and Simbu women specifically, currently predominate in Lae (and not Port Moresby) for the same reason. Bamu women have since the mid- to late 1960s been exploited sexually on Daru in a form of sexual networking commonly found throughout PNG and known as tu kina bus, or two-kina bush prostitution, known locally as sagapari or 'small mangrove garden' (Hammar n.d.). That ethnic majority Kiwai and to a lesser extent, Suki and Gogodala women, predominated in other forms of sexual networking on Daru but did not engage in tu kina bus (until just recently), speaks 
to common ethnic/tribal/racial segmentations of local sex industries. Papuan females have quickly come to 'rule' in Port Moresby's motels and night-clubs and the agency they exhibit (Delta 2005) is laudable, but it seldom undermines, as it tussles with, the structural forces that put them there.

\section{Daru}

Daru has been an administrative center since 1893, hosting since that time sailors and missionaries, sea cucumber and pearl-shell collectors and traders, and members of probably 30 different tribes. Economic downturns, the flight of expatriates following Independence (1975), traditional sexual license, and worsening access to health and educational services have produced five different, although overlapping forms of commercial sexual networking.

In the 'family' form male relatives and 'intimates', mostly from Kiwai and Bamu tribes, find generally older, mostly married, wage-earning sexual partners for their daughters, sisters, wives and girlfriends, aged 15 to 45 . Subsequent sexual activities that take place in their own houses, at public drinking locales and in nearby bush areas put food in the pot, money in the pocket (including of the male relatives and intimates), and tellingly, beer on the verandah. Rotmeri are poor, young, and pushed by parents, boyfriends and husbands into extremely opportunistic sex along streets. Mostly unmarried, somewhat older Kiwai, Bamu, Suki and Gogodala women engage in a 'freelance' form of sexual networking (though no one in PNG is ever fully independent) for money (or promise thereof), alcohol and food from public servants, sailors and crocodile skin and sea cucumber buyers. The 'women with sex broker' form involves Kiwai, Gogodala, Bamu and Suki women who also work freelance, but on whose behalf sex brokers solicit customers from amongst businessmen and visiting mainland villagers, especially public servants. In 1990-2, it was provincial- and national-level government workers who predominated as customers by a long stretch. In exchange for free alcohol, food, tobacco, betel-nut and 20 percent of the women's earnings, sex brokers provided escort and a modicum of protection. They also brokered marriages and sold sexually their own wives and female relatives.

The most starkly patterned form is called sagapari, which is also a public toilet and rubbish dump, which once involved only Bamu women as sellers and non-Bamu as buyers of sex that was had on the ground, standing up and atop impromptu beds. For the first time, though, it now involves Kiwai women and costs K5-10 or more. Daru informants said that things changed when 1) sagapari moved to its new location (away from Bamu settlements, toward Kiwai) on the 
other side of the island between swamp and cemetery, and 2) a Bamu woman was decapitated and dismembered there. It was for decades located adjacent to either wharf or to hospital (hence another indicative name Dokta Point).

\section{Lae, Morobe Province}

Sexual networking in Lae is similarly ubiquitous, but the more commercialised forms involve almost no local females, most being highlander, and specifically Simbu. Quasi-brothels exist in a medium-covenant house near the Milfordhaven Road roundabout (Delta 2005) and in Top-Town at $1 / 2$ Street in a house that until recently doubled as an NGO office. Girls and women solicit in town at well-known betel-nut selling stands and at the autoport-based kai-bars (PNG 'fast-food' joints). Some are directed by 'was-man', the male relatives who 'pull' customers from streets and public drinking locales. Caucasians and Asians drive around town looking for females who, like their counterparts in Port Moresby, can communicate much (sexual availability) with little (hand and eye 'actions'), including their desire to become temporary girlfriends and 'wives'. At dusk the sexual and other activities of the orphaned and otherwise abandoned youth emerge starkly. Bush areas, doorways and stairwells are used by truckers, security guards, policemen and others, who purchase oral sex and more from boys and girls. Many guest-houses are popular hubs of sexual networking, and both 'freelance' women and room cleaners and associated female staff will accept bas fe (literally 'bus-fare', but more than 70 toea) in exchange for sex. At the Lae Football Association club-house reside 10-12 young highlander females (again, mostly Simbu) who are sexually available on-site and off. The loungebars inside several upper-end hotels bustle with women mostly from Simbu and Western Highlands Province, again, available for one-off sex or temporary relationships, and just opposite the front-gate at one particular hotel nightly cluster 5-15 females and was-man. At one motel near the hospital, girls and women seek entrance through the security gate or lounge at poolside, both soliciting customers on their own and engaging security guards and drivers who, for money, small goods or free sex, will also solicit for the women. The Planet Rock night-club allows women free entrance each Wednesday. Sexual networking there involves mostly younger nationals, but at each venue other favours, gifts and commodities are given, received, bartered, or sold, such as gate-fees, pitchers of beer, money, transportation, accommodation and clothing, among other things, and services that serve to heighten the promise of relationships.

Lae has the country's second-largest tu kina bus ples, located opposite ANGAU Memorial Hospital. At any one time a dozen or more 35-45 year-old highland women, many bearing literal stigmata in the form of cuts, bruises, scars and 
broken and missing teeth, solicit on the edges thereof and along the road. They also visit betel-nut selling stands, play cards and themselves sell betel-nut and other small goods to solicit customers. Police harassment and customer violence are common. Many women emerged from unhappy, often violent marriages, though they seek marriage again, preferring possible biological death to likely social leperhood.

\section{Port Moresby}

Only the danger-loving would attempt to nail down precisely all of the forms and locations of Port Moresby's exploding sex industry. Most observers accept the presence of at least a dozen or so formal or quasi-brothels. One is located in Boroko behind the canteen opposite the main entrance of the Port Moresby General Hospital, another being located near the Manu autoport, and many more pamuk haus (residences of women and girls dubbed prostitutes) are sheltered behind 'legitimate' motels, clubs, tradestores and guest-houses (Delta 2005; see also Fletcher and Gonapa this volume; Stewart this volume). One popular guest-house rents rooms on both nightly and 'transit' bases and is attached to a disco. Sex is easily available to mostly national clientele, cheap and like many other sex industry locales, very much a family affair (Lepani 2004). As is statistically frequent and culturally normative, sellers and buyers are related by the admirably diverse array of blood, marriage and 'fictive' forms of kinship. Connecting another motel to Bampton Street, until 2006, was a string of faiv kinahaus in each of which reside six to eight Papuan females mostly from Kerema and eastern Gulf villages 'along the highway connecting villages of Iokea, Moveave and Lilifaru' (Delta 2005). They served mostly national publicservant and clerk clientele, especially at lunch time, for K5-10. Many sexual assignations to hotel guests were until recently handled by a highlands female manager who also distributed condoms and protected the women from legal and customer violence. ${ }^{4}$ Each place is also connected to nearby betel-nut and marijuana-selling operations. Male intimate 'pullers' also solicit for these 'roadrunners', who are decidedly not rot meri. A quasi-brothel operates about 500 meters away near the AON House office tower, whose occupants then solicit sexual services in nearby parks, directly on the street and at supermarket fronts and the Post Office (Delta 2005). The Wanigela round-about is a popular pick-up spot in the evenings, and cell phones are used.

At such venues, the relations of class, culture, race and gender don't so much melt as clash. With wife and daughter in tow, on my first visit to one of Port

4 Following its sale and takeover by new management, the Ela Beach Hotel seems less enabling now of prostitution. 
Moresby's several venues at which British expatriates cavort with young, onsite resident Papuan females, a drunken patron was allowed twice (but only once accurately) to blast away with shot-gun at a cardboard-cutout of Osama bin Laden displayed above the back-bar. To take a female out of the loungebar and disco area into one's guest-house room or off-premises altogether is to make a 'champagne arrangement' with the manager and purchase for K100 a bottle of champagne (in essence, the 'bar fines' of Okinawa, Thailand and the Philippines). In this and other clubs catering to expatriates, young resident Papuan females earn commission on high-priced drinks they convince men to purchase. They complain of perpetual hunger and also of beer bellies.

\section{Moro, Southern Highlands Province}

When it's time for the [male] landowners to get their royalty payments [for owning the ground atop which sets the oil pipeline], that's when we charge more steeply ... Okay, some of the [oil pipeline] workers, the security guards and so forth, they leave lunch for us [i.e., put take-away food on the ground] and then tell us, tell us: 'you and I go have sex' . . .

This 35-year-old Huli woman recounts desperately hungry women-not housewives, though many are married-who have migrated to the Moro base camp from Tari villages and who will have sex with security guards and kitchen staff for as little as plet kaikai, a plate of take-away food. Just as Huli men have 'followed the money' available along the Lake Kutubu oil pipeline by 'marrying in' and seeking employment (some Foi/Foe and Fasu/Faso villages are now half-Huli), so have Huli women pursued workmen and landowners through sex to earn money but also by trying their best to arrange temporary or more permanent relationships. Huli women were 'traditionally' wooed by evocative poetry and singing in dawe anda (house/men), but many of these have since turned into quasi-brothels and contested sites of 'modern' masculinities (Wardlow 2006, see also Haley this volume). Now they can be had sexually for as little as K5-10 in Moro's tu kina bus ples though they sometimes charge K50100 when the monies are flowing. Despite the stigma they suffer socially and corporeally, and however unrealistic it may be, their goal is most often a 'stable' relationship, one from which springs forth gifts, money and commodities. This is why so few women charge money up-front for sexual services, precisely the female agency that men see as provoking beatings. Of Holly Wardlow's pasindia meri informants in the Tari Basin, not one said that she charged money up-front (2004, 1032).

5 Audiotaped, transcribed focus group discussion conducted in Tok Pisin by Herick Aeno and Phili Manove, Moro, Southern Highlands Province, February 7, 2005. 
As such, the strategies that Tari, and to a lesser extent, Mendi and Mt Hagen women follow are clear and consonant with those of their counterparts elsewhere. Moro maket bustles with activity from Monday night until Thursday morning. Trucks and PMVs filled with people and cargo go to and come from Mt Hagen, Mendi, and especially Huli villages adjacent to the main highway and those connected by feeder roads. At, inside of, and due to the Moro maket, sexual networking connects men to women, cargo to destination, tribe to resource, and of course, pathogen to infectee. Security guards, policemen, local landowners, visiting villagers and company workmen constitute the bulk of the clientele, although base-camps at Ridge and Moro are theoretically lockeddown and prohibitive sexually. Oil Search Limited (OSL) states a policy of zerotolerance for in-room, cross-gender socialising, designed to protect not only female privacy and safety but also the potential transmissive risks of fly-in, fly-out shift work. Nevertheless, many workers from OSL (and virtually all male employees of the local landowner companies) come and go as they please. Another Huli woman explained that 'they just suck the cocks of the security', meaning that the workers don't bribe security guards to let women inside the camp, but rather, to allow them passage to Moro maket and multiple adjacent $t u$ kina bus ples. ${ }^{6}$ Sexual networking is so intimately tied to the political economyas is prostitution to marriage - that women come to know precisely the timing and location of the next pay-out. There is a 'guest-house' along the main road that is managed by a male intimate and that functions as a brothel. It is owned by a Port Moresby-based man from a nearby village, Kaipu, that has erected both fence and sign-board so as to prevent the entrance of sin and risk in the form of darts, Bingo, cards-playing, betel-nut chewing, alcoholic beverages and pasindia man/meri (those who engage in commercialised sex).

\section{Let's Talk about Sin}

Private citizens and state and church representatives have for more than two millennia discussed the merits and drawbacks of prostitution. Far less tolerant church pressure put recently upon the state in Australia and elsewhere to stamp it out 'has largely hidden the compromises of the past' (Perkins 1991, 18), including direct church complicity. In PNG, in many ways 'the church' supersedes 'the state' in terms of financial resources, the delivery of services and moral force. Due to the arrival of AIDS to PNG, calls have been made increasingly to decriminalise if not also to legalise prostitution in the form of state-sponsored brothels. One strand of discourse (not quite yet activism) claims (not quite yet argues) that lowered transmission risks would result, and that the innocence of youth, chastity of wives and public health of the nation would

6 Author's fieldnotes, 26 January 2005, Moro base camp. 
thereby would be protected. You can't make sexual desire go away, prostitution is 'the world's oldest profession' and the state would profit from its taxationso say proponents. These claims are voiced on the street, uttered by the welleducated, enunciated by higher-ranking health officials, and published in newspaper letters and editorials. At least one parliamentarian supports this (see Fletcher and Gonapa this volume).

A second discursive strand suggests that state sponsorship of brothels would yet further compromise if not altogether disqualify PNG as being 'a Christian country'. Along with alcohol, marijuana, Em-TV (and MTV), and the rise of two dangerous things-raskolism and women's consciousness - this most recent call further to secularise a nation that was supposed to have been founded on Christian principles - and which are stated in the national Constitutionis just going too far. This rhetoric comes from churches, community-based organisations, activist housewives and village elders. The writer ('Who Is the Man Indeed' of a letter to the editor entitled 'Gender equality could cause more harm than good' argued that 'empowering women' just isn't common sense: 'Whoever heard of men's days or men's awards?', he complained (Post Courier 14 April 2008). Few of them, however, comment much about nearly unchecked forms of misogyny - that is, 'unchristian behaviour' - ranging from the torture and killing of suspected witches and pack-rape, to wife-bashing and sexual molestation committed by male relatives, school-teachers, family friends and, if newspapers are to be believed, church leaders.

A third strand of commentary suggests that not everyone is so sad to see AIDS come to PNG. That is, sikAIDS, em $i$ kam long Bikpela, em i pe bilong sin bilong $o l$, meaning that AIDS is God's just punishment of foul sinners as we approach the End Times. 'AIDS' helps to reveal the sin on which Christian doctrine and activity feed, just as unemployment helps to perpetuate capitalism. In April 2006 I interviewed a hospital CEO in the highlands who provided a pick-up truck and a loudspeaker to those recently diagnosed as HIV positive, so that they could warn their communities of their new status. Since Holly Wardlow first alerted me to this discourse among health workers in the Tari area, I have heard other health workers express the desire that a few religious leaders die from AIDS so as to reveal their far more damaging hypocrisy (see also Wardlow 2008).

I believe and predict here that despite the moral force exhibited by the numerically superior proponents of the second and third strands of discourse, proponents of the first one will win out. I say this for essentially two reasons. First and most obviously, the legalisation of prostitution and the state sponsorship of brothels would enshrine and further support male sexual privilege. Had male sexual privilege not been protected at all costs, then public health messages and campaigns would have intruded upon companionate marriage a long time 
ago and legal authorities would have begun to take sexual violence seriously. They haven't. Condoms would have emerged as de rigeur in sex per se, not just in 'high-risk' anonymous sex. They haven't. Second, the erection of brothels would provide two kinds of extremely powerful object lessons: 1) regarding the reality of sexual desire outside the bounds of the marital chambers, locating and attempting to channel it in known and finite places where by definition the sexually incontinent would go, and 2) regarding the continuing rhetorical usefulness of the existence of the two Marys in Christian discourse, one a sexually inexperienced Madonna, the other (not my term), a whore (Mary Magdalene). I am not a supporter of state-sponsored brothels, though I support decriminalisation. However well state-sponsored brothels express dialectical tensions in PNG regarding social structure, desire, political economy, culture, Westernisation, Christianity and psyche, they make a poor public health response.

\section{Brothels, Harm and the Politics of AIDS}

I contend that calls for the state to erect and regulate brothels are ill-conceived. Most obviously, brothels would neither decrease nor deflect putative male sexual excess so much as re-channel and re-locate it, just as zoning regulations don't make sex work disappear so much as move it around. By similar logic, if it is true that Em-TV and MTV titillate prurient interest, that 'blue-movies' make men want to rape, and that Australia's People magazine is pornographic, ${ }^{7}$ then brothels would surely make male sexuality run riot. As I see it, and even if one grants (as I do not) that state-sponsored brothels could theoretically decrease HIV transmission appreciably in a country such as PNG, this is what would have to come about:

- the building and adequate maintenance (in terms of structural, aesthetic and hygienic considerations) of many more brothels than the state can afford to erect; 20-25 brothels would need to be erected in medium-sized provinces, at least 15-20 in the low-density provinces, 20-30 in Lae and Mt. Hagen alone, and perhaps 80-100 in the NCD;

- the complete overhauling, re-tooling and constant monitoring of the efficacy of the requisite medical and statistical-regulatory services, far in excess of what the state can afford; the state would need to test and re-test, treat and re-treat both the females conscripted into public health duty and, of course, their customers, and for surveillance to work, compare all such data collected as against those collected about sexual networking occurring outside brothels;

7 It is, in fact, specifically banned by Oil Search Limited. 
- political re-education of the 'disciplined' forces who would police and regulate such brothels away from tyrannical misogyny; additional funds would be required, of course, to address the monetary and other interests such forces currently have in informal sexual networking, including sexual gratification and bribery (how many Papua New Guinean women would let their husbands work 'security' there?);

- more political re-education regarding the necessity of 100 percent condom usage, especially with regular customers, would-be boyfriends and husbands, and especially wantoks (people who share tribal, geographic, and especially linguistic affiliation); public health campaigns have yet even specifically to target commercial transactions (beyond excoriation of 'the pamuku'), much less those in a companionate setting;

- the building of brothels that would be equal parts geographically wellplaced and aesthetically pleasing, sufficient to usurp and absorb the function of other forms of sexual networking, such as tu kina bus and street-walking; not only is this extremely unlikely to happen (what to do with the brothel when the timber camp shifts or with the employees when the owner is deported?), but it would price sex well beyond the abilities of vast legions of PNG men to pay;

- added protection ('policing the police') provided to the women regarding the sexually predatory nature of many who would 'regulate' prostitution;

- a collective coming to terms with the fact that state-sponsored brothels would further disable awareness that HIV is firmly established in marriage and other forms of companionate relationship; it would require a brave political act to acknowledge the role of expatriates (Caucasian and Asian) in sexual networking.

\section{Conclusions}

By looking at sexual networking as being ultimately a social process that has undetermined outcomes - instead of as a thing that is opposed to heterosexual monogamy - my argument to this point has been four-fold. First, I have underscored the obvious value of ethnographic data in informing such important public policy debates as this. Unfortunately, despite such relevant data having been collected in abundance for nearly three decades, and despite frequent calls that more be collected, extremely few of them have been put directly to use, and only rarely have critical theory and social research perspectives been aired.

What such data and perspectives show is the painfully obvious fact, that, second, we have a Papua New Guinean epidemic on our hands, one that is as little Ugandan as it is Australian. Just because brothels in Nevada can demonstrate 
99.9 percent rates of condom usage doesn't mean that such will happen in PNG, although that would, of course, be a wonderful thing. If they ever get there in the first place, condoms are purposely allowed to expire in health facilities (Hammar 2006, 2008b). Susan Hunter's analysis of the structure and movement of the AIDS epidemic in PNG is at many points dead-on in this regard. She concludes in a recent report, for example, that, '[u]nlike Thailand and Cambodia, small states where aggressive condom promotion campaigns through relatively organised sex industries have contained the epidemic, knowledge of AIDS among PNG's citizens is low, condom use and availability is not widespread, and commercial sex is largely informal' (Hunter 2005, 14). Papua New Guinean modes of kinship and marriage were so fundamentally misunderstood by the application of 'African models' that one anthropologist asked: 'Are there Groups in the New Guinea Highlands?' Many now are lamenting what Ben Reilly calls the 'Africanisation of the South Pacific' (2000) in regards to expectations about liberal democracy's centralising tendencies when situated within decentralising social formations (see O'Keefe this volume). I have yet to hear Zambians say that 'if we don't look out, we'll have a Papua New Guinean epidemic on our hands'.

Indeed, the Papua New Guinean flavour and pace of the expanding and overlapping STD and HIV epidemics are being overlooked in favour of the application of models from elsewhere that are known more by acronym and abbreviation (e.g., 'ABC', '3X5', 'MSM', 'HRS' etc.) than by careful conceptualisation and operationalisation. In the final analysis, the national-level response to AIDS in PNG has been a centralised one, driven by internal PNG politics and the needs of external donors, specifically for the placement of structures, not the forging of sustainable relationships. Unfortunately, the social, economic, sexual, religious and pathogenic forces that propel AIDS forward are decentralising, centrifugal ones. If 85 percent or thereabouts of the total population still live in rural areas but for countless reasons travel and migrate far and wide, that's how infections must also be occurring. The site of detection (NCD) has been fetishised all out of proportion to the real complexity of transmission dynamics. People from A get infected in $\mathrm{B}, \mathrm{C}$ and $\mathrm{D}$, and get tested in $\mathrm{E}$ and even $\mathrm{F}$ at a bare minimum.

Third, there is merit to accepting the functions, the social origins and the likely continuance of a 'weak state' in PNG. I don't want (and I certainly don't expect) the PNG state to be 'strong'; I want it to be just. Papua New Guinea, on the other hand, not the state, is strong in ways that are neither addressed, nor valourised in the fight against AIDS. PNG is characterised by a multiplicity of Christian denominations, by extreme linguistic diversity, by pronounced cultural pluralism and by behavioural promiscuity in the neutral sense of less determined options of residence, work and sexuality. These are the kinds of factors that have been the hallmarks of effective, humane and above all, sustainable responses to AIDS elsewhere, for example, Brazil, and among gay 
and lesbian communities. Brooke Schoepf, among others writing about Uganda's 'success story', has highlighted that President Museveni's government takeover in 1986 'fostered a vibrant civil society of voluntary associations that eventually included more than 1,000 AIDS NGOs . . This exemplary openness created an enabling context for change, with debate, dialogue and action' (Schoepf 2003, 553). This has not yet been allowed to happen in PNG.

Fourth, expecting the state to sponsor brothels wildly overestimates the statistical- and medical-regulatory powers requisite to bring about the kind of individual and community changes that, say, the People's Republic of China fomented in quickly eradicating gonorrhea. Such calls fail to question the 'discipline' of the police, landowners, soldiers, public servants and security guards who already drive the 'demand' side of the ledger insofar as they pay directly for sex (although not always with money); facilitate sexual networking by providing venues, vehicles, other customers, 'security', privacy and alcohol; and hyper-exploit women and girls by soliciting free sex in a 'disciplined' setting (such as in the back of a police vehicle, in an office at lunch time, or in a jail cell), by committing individual and pack-rape (sometimes alongside other policemen), and by not fulfilling their duty to prevent, investigate and successfully prosecute cases of sexual violence. ${ }^{8}$

In conclusion, one cannot much improve upon the words of Friedrich Engels of more than a century ago, which noted the inherent gendered double standards of the culture and political economy of the time as regards sex. Were the state in PNG to sponsor and attempt to regulate prostitution, women would become 'ostracised and cast out of society in order to proclaim once more the fundamental law of unconditional male supremacy over the female sex' (quoted in Perkins 1991, 178). In PNG, calls to erect brothels fail to acknowledge both rampant male sexual privilege and painfully sex-negative attitudes formed equally by church and more 'traditional' sources and practices. Were they finally and squarely to address the clear risks of the 'gift' of unprotected sex, public health campaigns and practitioners would usefully expand, not further narrow, sexual repertoire and partner choice. Church and community leaders, politicians and businessmen, athletes and expatriates, not to say doctors and nurses, too, should be targeted, not just 'CSW' (Commercial Sex Workers) and 'MSM' (Men who have Sex with Men). Their charge should be to help foster sex-positive, not sex-negative attitudes. Their mandate must be that PNG needs more sex, clearly, but that which is better and more protected because it is more consensual, certainly more pleasurable and hopefully less infected.

8 Not all policemen are bad, of course, and not all of them take part in prostitution and pack rape. Wardlow $(2001,3)$, for example, writes that 'until the [Tari] hospital ran out of money, it was regular practice for the STD clinic to hire a band of policemen to burn down dawe anda sites [i.e., quasi-brothels]'. In Moro, however, by various means we can confirm intimate engagement and facilitation of prostitution, including in poor facsimile of Wardlow's dawe and near work-camps. 


\section{Acknowledgements}

Two readers have to be acknowledged pseudonymously for their input: Gamo, my colleague at the IMR, because she is my sister-in-law and has helped me understand sexual networking and shown exemplary style in investigations thereinto; and Kikori Delta, a well-placed expatriate financial advisor whose specific knowledge of sexual networking issues is too great and whose insight into places and people I describe here is too keen to be published openly at this time. Thanks go, too, to three colleagues I can acknowledge by real namesVicki Luker, Sinclair Dinnen and Susan Hunter-whose continual support, sharp analytical eye and ongoing friendship mean a lot to me. Holly Wardlow's exemplary work among Huli pasindia meri ('passenger women' who exchange sex for money in protest at male relatives who have failed them) also deserves a round of applause (see especially Wayward Women: Sexuality and Agency in a New Guinea Society 2006; see also Hammar 2008b). Ross Hutton from Oil Search Ltd. sponsored my trip to the Tari Basin in 2006, for which I am extremely grateful.

\section{References}

Delta, Kikori (a pseudonym), 2005. Personal communication.

Gammage, Bill. 1998. The Sky Travellers: Journeys in New Guinea, 1938-1939. Melbourne: The Miegunyah Press (for Melbourne University Press).

Gare, Janet, Tony Lupiwa, Dagwin Suarkia, Michael Paniu, Asibo Wahasoka, Hannah Nivia, Janet Kono, William Yeka, John Reeder and Charles Mgone. 2005. High Prevalence of Sexually Transmitted Infections among Female Sex Workers in the Eastern Highlands Province of Papua New Guinea. Sexually Transmitted Diseases 32 (3):466-72.

Gregory, Chris. 1982. Gifts and Commodities. London: Academic Press.

Haley, Nicole. 2008. When there's No Accessing Basic Health Care: Local Politics and HIV/AIDS at Lake Kopiago, Papua New Guinea. In Making Sense of AIDS: Culture, Sexuality, and Power in Melanesia, ed. Leslie Butt and Richard Eves, 24-40. Honolulu: University of Hawai'i Press.

Hammar, Lawrence. n.d. Sex and Secrecy in the South Fly: tu kina bus in historical perspective. Manuscript submitted to Oceania.

Hammar, Lawrence. 2008. Rhetorics of Risk and Foreign Object(ion)s. Pacific AIDS Alert Bulletin 33. 
Civic Insecurity

Hammar, Lawrence. 2006. 'It's in Every Corner Now': A Nationwide Study of HIV, AIDS and STDS. Final Report of a three-year study. Operational Research Unit. Goroko: Papua New Guinea Institute of Medical Research.

Hammar, Lawrence. 2004a. Sexual Health, Sexual Networking, and Sexually Transmitted Disease in Papua New Guinea and West Papua. Papua New Guinea Medical Journal 47:1-2.

Hammar, Lawrence. 2004b. 4,275 and Counting: Telling Stories about Sexually Transmitted Diseases on Daru Island, Western Province. Papua New Guinea Medical Journal 47 (1-2).

Hammar, Lawrence. 1998. AIDS, STDs, and Sex Work in Papua New Guinea. In Modern Papua New Guinea, ed. Laura Zimmer-Tamakoshi, 257-296. Kirksville, Missouri: Thomas Jefferson University Press.

Hershberger, Ruth. 1948. Adam's Rib. New York: Harper and Row.

Hunter, Susan. 2005. HIV/AIDS, Women and Children in PNG. Part II of Families and Children Affected by HIV/AIDS and Other Vulnerable Children in Papua New Guinea: a national situation analysis. Draft report, used by permission of the author.

Lepani, Katherine. 2004. Personal communication.

McCurry, Justin. 2005. Solace for Virgin Wives of Japan. Guardian Weekly, April 15-21, 18.

Perkins, Roberta. 1991. Working Girls: Prostitutes, their Life and Social Control. Canberra: Australian Institute of Criminology.

Rees, Sian. 2002. The Floating Brothel: The Extraordinary True Story of an Eighteenth-Century Ship and its Cargo of Female Convicts. London: Hyperion.

Reilly, Ben. 2000. The Africanisation of the South Pacific. Australian Journal of International Affairs 54 (3): 261-8.

Schoepf, Brooke Grundfest. 2003. Uganda: Lessons for AIDS Control. Review of African Political Economy 98: 553-72.

Shostak, Marjorie. 1981. Nisa: The Life and Words of a !Kung Woman. Harvard: Cambridge University Press.

Sinclair, James. 1981. Kiap: Australia's Patrol Officers in Papua New Guinea. Sydney: Pacific Publications. 
Tiwara, S., M. Passey, A. Clegg, C. Mgone, S. Lupiwa, N. Suve and T. Lupiwa. 1996. High Prevalence of Trichomonal Vaginitis and Chlamydial Cervicitis among a Rural Population in the Highlands of Papua New Guinea. Papua New Guinea Medical Journal 39: 234-8.

Wardlow, Holly. 2001. 'Free Food, Free Food!': 'Traditional' Rituals of 'Modern' Manhood among the Huli of Papua New Guinea. Presented at the 3rd Annual IASSC conference, October 1-3.

Wardlow, Holly. 2008. 'You Have to Understand: Some of Us are Glad AIDS has Arrived': Christianity and Condoms among the Huli, Papua New Guinea. In Making Sense of AIDS: Culture, Sexuality, and Power in Melanesia, ed. Leslie Butt and Richard Eves, 187-205. Honolulu: University of Hawai'I Press.

Willis, Ian. 1974. Lae: Village and City. Melbourne: Melbourne University Press.

Yerkes, Robert. 1943. Chimpanzees. New Haven: Yale University Press.

Zimmer-Tamakoshi, Laura. 2004. Rape and Other Sexual Aggression. In The Encyclopedia of Sex and Gender, ed. Carol Ember and Melvyn Ember, 230243. Amsterdam: Kluwer. 